\title{
The Roles of Nanoparticles in Stem Cell-Based Therapy for Cardiovascular Disease
}

\author{
Yuting Sun ${ }^{1+}$, Yuexin Lu't, Li Yin' and Zhenjie Liu' ${ }^{2 *}$ \\ 'Department of Surgical Oncology, The Second Affiliated Hospital, Zhejiang University School of Medicine, Hangzhou, China, \\ ${ }^{2}$ Department of Vascular Surgery, The Second Affiliated Hospital, Zhejiang University School of Medicine, Hangzhou, China
}

Cardiovascular disease (CVD) is currently one of the primary causes of mortality and morbidity worldwide. Nanoparticles (NPS) are playing increasingly important roles in regulating stem cell behavior because of their special features, including shape, size, aspect ratio, surface charge, and surface area. In terms of cardiac disease, NPs can facilitate gene delivery in stem cells, track the stem cells in vivo for long-term monitoring, and enhance retention after their transplantation. The advantages of applying NPs in

OPEN ACCESS

Edited by:

Paolo Madeddu,

University of Bristol, United Kingdom

Reviewed by:

Tomasz Jadczyk,

Medical University of Silesia, Poland

Wuqiang Zhu,

Mayo Clinic Arizona, United States

*Correspondence:

Zhenjie Liu

lawson4001@zju.edu.cn

tThese authors have contributed equally to this work

Specialty section:

This article was submitted to Tissue Engineering and Regenerative Medicine,

a section of the journal Frontiers in Bioengineering and Biotechnology

Received: 21 March 2020

Accepted: 22 July 2020

Published: 14 August 2020

Citation:

Sun Y, Lu Y, Yin L and Liu Z (2020) The Roles of Nanoparticles in Stem Cell-Based Therapy

for Cardiovascular Disease.

Front. Bioeng. Biotechnol. 8:947.

doi: 10.3389/fbioe.2020.00947 peripheral vascular disease treatments include facilitating stem cell therapy, mimicking the extracellular matrix environment, and utilizing a safe non-viral gene delivery tool. However, the main limitation of NPs is toxicity, which is related to their size, shape, aspect ratio, and surface charge. Currently, there have been many animal models proving NPs' potential in treating CVD, but no extensive applications of stem-cell therapy using NPs are available in clinical practice. In conclusion, NPs might have significant potential uses in clinical trials of CVD in the future, thereby meeting the changing needs of individual patients worldwide.

Keywords: nanoparticles, stem cell, cardiac disease, peripheral vascular disease, regeneration

\section{INTRODUCTION}

Cardiovascular disease (CVD) is one of the primary causes of mortality and morbidity around the world (GDB 2017 DALYs and HALE Collaborators, 2018). According to the latest data, ischemic heart disease remains the primary cause of death among various CVD (Prajnamitra et al., 2019). Although the current pharmacological treatments and surgical procedures have improved the survival rate of the patients with cardiac disease, none of these therapies mentioned above can replace the cardiac tissue lost after infarction (Calin et al., 2013). Peripheral vascular disease (PVD), which is characterized by the narrowing of the peripheral vasculature, has a significant unfavorable impact on the health of patients (Bartolo et al., 2019). However, traditional strategies have limited efficacy in treating PVD (Tu et al., 2015; Hedhli et al., 2017). Therefore, regenerative medicine is urgently needed to achieve the functional recovery of damaged tissues. Stem cell therapy is a potential alternative approach to achieve therapeutic angiogenesis with several unique advantages over growth factor therapy or gene therapy. However, the efficacy of stem cells to treat CVD remains controversial. A meta-analysis of 52 preclinical animal studies of MSC therapy for ischemic heart disease showed that it is safe and associated with moderate $(\sim 7.5 \%)$, but significant improvements in left ventricular ejection fraction, but the effect of cell therapy on left ventricular ejection fraction decreased slightly after 8-week follow-up (van der Spoel et al., 2011). 
Nanoparticles and structures have been used by humans in the fourth century $\mathrm{AD}$ by the Roman, which demonstrated one of the most interesting examples of nanotechnology (Bayda et al., 2019). The use of nanoparticles (NPs) can help overcome some of the obstacles as mentioned above and augment the benefits of cell therapy through delivering genes to stem cells, enhancing stem cell retention, facilitating the proangiogenic effect of stem cells and mimicking the extracellular environment. This review mainly focuses on the types, physical characteristics, adverse effects of NPs, and the mechanisms by which NPs have improved stem cell-based treatment strategies for cardiovascular regeneration in recent years. Furthermore, we also aim to illustrate the challenges that we face in applying nanotechnology for cardiovascular regeneration and its prospects for the future.

\section{STEM CELL TYPES}

In terms of heart disease, mesenchymal stem cells (MSCs) constitute a potential option for cell-based therapy to treat cardiac disease. The results of the RIMECARD clinical trial showed that human-derived MSCs could improve the cardiac function of patients with myocardial infarction (MI) (Hare et al., 2009). The POSEIDON-DCM trial showed that MSCs could reduce fibrosis in scarred tissues (Hare et al., 2017). Additionally, a clinical trial aiming to investigate the safety and efficacy of the intramyocardial implantation of allogeneic MSCs in patients with end-stage ischemic cardiomyopathy has been initiated, but the results have not yet been reported. Human-derived induced pluripotent stem cells (hiPSC) constitute another stem cell type that might be suitable for stem cell-based therapy, and two recent studies demonstrated that human embryonic stem cellderived cardiomyocytes enhance cardiac function in macaque monkeys with large MI areas (Shiba et al., 2016; Liu et al., 2018). However, no clinical trials have been demonstrated their effects on patients with cardiac disease. In terms of vascular disease, MSCs play a role in vessel regeneration that is as important as their role in cardiac disease. A pilot study demonstrated that adipose-derived MSCs injections might be a safe alternative to achieve therapeutic angiogenesis in patients with critical limb ischemia (a severe manifestation of PVD). However, the sample size was small, and the results are, therefore, insufficient (Lee et al., 2012). A phase II clinical trial shows that the use of MSCs combining with endothelial progenitor cells (EPCs) therapy is safe and effective for increasing blood flow in the ischemic legs of patients with limb ischemia (Lasala et al., 2012), also, EPCs have been applied in bovine models and murine models of peripheral arterial disease and can be isolated from hiPSC (Asahara et al., 1997; Boyer et al., 2000; Samuel et al., 2013; Peters, 2018).

However, several limitations of treating CVD with stem cells exist, including the low survival rate of implanted cells (Yun and Lee, 2019), the rapid apoptosis of the transplanted cells because of exposure to a hypoxia environment (Tang et al., 2005) and the poor survival of the transplanted cells caused by the inflammatory and proapoptotic environment in ischemic tissue (Zhang et al.,
2001; Toma et al., 2002). Many studied have shown stem-cell therapy with NPs.

\section{NPS STRUCTURE AND TYPES}

\section{The Definition of NPs}

The published recommendation for the definition of nanomaterials refers to a nanomaterial as a natural, incidental or manufactured material consisting of particles in an unbound state, aggregate or agglomerate consisting, and indicates that 50\% or more of the particles should be in a size distribution range from 1 to $100 \mathrm{~nm}$ based on one or more external dimensions (Piperigkou et al., 2016). Because of their unique physical and chemical properties, NPs have played an increasingly important role in determining and regulating stem cell behavior, including tracing the fate and distribution of stem cells in vivo, inducing directed differentiation of stem cells, ascertaining the origin of stem cell diseases, stimulating the paracrine behavior of stem cells and regulating the microenvironment of tissues around stem cells (La Francesca, 2012; Le et al., 2017). Various types of NPs exist, including metal NPs, SPIONs, SNPs, carbon NPs. In this section, we will review the common types of NPs used in cardiovascular regeneration.

\section{Physicochemical Properties of NPs Particle Size and Surface Area}

Particle size and surface area play significant roles in the interaction between materials and biological systems (Talkar et al., 2018), for example, how a system responds to absorb, distribute, and eliminate the materials (Powers et al., 2007). According to the size of the NPs, the uptake modes can be categorized as phagocytosis and pinocytosis. Large particles are mainly absorbed through phagocytosis, while small particles can be absorbed through either phagocytosis or pinocytosis, with the larger particles internalized by the cells with the most enormous phagocytosis capacity (Aillon et al., 2009).

\section{Particle Shape and Aspect Ratio}

The processes of endocytosis and phagocytosis are affected by the shape characteristics of the material. Spherical particles are more natural to endocytose than particles of any other shape. Non-spherical nanomaterials are more likely to flow through capillaries, causing other biological consequences (Lee et al., 2007; Verma and Stellacci, 2010; Kim et al., 2012).

\section{Surface Charge}

The surface charge of NPs has a significant influence on the biological system, and the surface charge on the particles determines many of their interactions (Georgieva et al., 2011). The mammalian cell membrane has a negatively charged surface. Therefore, cationic particles are more likely than negative or neutral particles to interact with cells.

\section{Other Characteristics}

The crystalline structure, aggregation potential, and surface coating of the NPs can also affect their biocompatibility and 
toxicity (Pietroiusti et al., 2011). Concentration may be the main factor contributing to the toxicity of large particles (Gatoo et al., 2014; Talkar et al., 2018).

\section{The Most Commonly Used Types of NPs in CVD SPIONs}

In magnetic resonance imaging (MRI), SPIONs exhibit magnetism in the region exposed to the magnetic field, and when the external magnetic field is removed, the magnetism of the SPIONs also disappears. SPIONs, as T2 magnetic contrast agents, mainly affect MRI R2 relaxation, shorten the T2 time, and weaken the weighted T2 signal. They are characterized by having a size in the nanometer range, with intense penetration, and a relaxation rate of $7 \sim 10$-fold higher than that of $\mathrm{Gd} 3+$ at the same concentration, which enables MRI at very low concentrations, revealing a region of signal reduction that forms a contrast with the signals of the surrounding tissues (Urdzíková et al., 2006). The magnetic properties of SPIONs, which are influenced by external magnetic fields, are used as cell markers (Cromer Berman et al., 2011). Among cell marker SPIONs, magnetic $\mathrm{Fe}_{3} \mathrm{O}_{4}$ has the most application prospects. SPIONs have the characteristics of superparamagnetism, low toxicity, excellent biocompatibility, and directional movement under an external magnetic field (Bull et al., 2014). These NPs have broad application prospects as cell markers, guide molecules, and probes for monitoring the therapeutic effect of stem cells on acute MI. Leveraging their magnetic properties, SPIONs are used in MRI to tag and, effectively trace cells to determine cell localization. SPIONs with particle sizes of $1 \sim 100 \mathrm{~nm}$ are not quickly engulfed by the reticuloendothelial system. SPIONs have a positive surface charge and often require surface modification because SPIONs without surface modification are unstable and tend to polymerize in the moist environments.

\section{Quantum Dots (QDs)}

Quantum dots are important nanoscale, low-dimensional semiconductor materials that, in three dimensions, do not exceed twice the exciton Bohr radius of the corresponding semiconductor material (Lei et al., 2008). QDs are generally spherical, and their diameters are usually between 2 and $20 \mathrm{~nm}$. Because of their unique optical properties (broad excitation and narrow emission spectra), they emit brighter and particularly stable fluorescence (Michalet et al., 2005). A previous study presented an immunomagnetic assay based on functionalized magnetic beads and detachable QDs for the separation and quantication of soluble CD40 Ligand (CD40 Ligand, also known as tumor necrosis factor associated activation protein, is related to atherosclerosis) from solution (Park et al., 2013). Recently, a study firstly reported that $0 \mathrm{D}$ titanium carbide MXene QDs could be incorporated into a chitosan-based hydrogel to create a $3 \mathrm{D}$ platform with enhanced physicochemical properties for stem cell delivery and tissue repair (Rafieerad et al., 2019). Furthermore, another study demonstrated that selenium QDs can prevent endothelial dysfunction and reduced the size of atherosclerotic plaque in aortic arteries (Zhu et al., 2019).

\section{SNPs}

SNPs are ultrafine with a size range from 1 to $100 \mathrm{~nm}$. Therefore, they have many unique optical properties in ultraviolet light, which can enhance the aging resistance, strength, and chemical resistance of other materials (Tang et al., 2012). SNPs can be divided into two categories: solid SNPs and mesoporous SNPs, both of which have the potential uses in stem cell therapy, including stem cell differentiation, imaging, and tracking (Tang and Cheng, 2013; Patel and Lee, 2015). Additionally, they have unique biological adaptability and show morphological adjustability plasticity (Slowing et al., 2008).

\section{Metal NPs}

Among various metal NPs, the most commonly used metalbased NPs consist of silver, gold, copper, iron, and zinc (Iravani et al., 2014; Kandi and Kandi, 2015). Nanomaterials, including gold NPs (AuNPs), demonstrated excellent biocompatibility (Hung et al., 2009b, 2012) and possessed unique optical and surface plasmon resonance properties (Singh et al., 2018). Numerous plants and microorganisms have the potential to produce AuNPs (Alcor et al., 2009; Singh et al., 2016, 2017; Sánchez-López et al., 2020). These biologically synthesized AuNPs have become potential options for use as biosensors and in immunoassays, targeting drug delivery, photoimaging, photothermal therapy, and photodynamic therapy (Singh et al., 2018). The functionalization of AuNPs may enable cardiomyocyte to differentiation to hiPSC (Jung et al., 2012; Patel et al., 2014). Additionally, AuNPs promoted the exosome secretion from MSCs and inhibited autophagy flux in MSCs (Arslan et al., 2013). Exosomes secreted by MSCs play an important role in ischemic disease and the inflammatory response. Promoting exosome secretion is of great significance for the use of MSCs in the treatment of MI, lower limb ischemia, cerebral infarction, and other diseases (Arslan et al., 2013; Chen et al., 2015).

\section{Solid Lipid NPs (SLN)}

Solid lipid NPs, with a size range of $50-1000 \mathrm{~nm}$, is composed of a solid lipid core surrounded by a layer of surfactants in aqueous dispersion, with multiple potential combinations of lipids and surfactants (Chauhan et al., 2016). SLN made their first appearance almost 25 years ago and are one of the newest members of the lipid-based nanocarriers family (Gasco, 2007; Satterlee and Huang, 2016). SLN among the most effective carriers for hydrophilic and hydrophobic drugs owing to their inclusion of cationic lipids, which provide a positive surface potential that favors binding to nucleic acids; and SLNs can be used for gene delivery, which provides a positive surface potential that favors binding to the nucleic acids like DNA, siRNA, miRNA (Naseri et al., 2015; Botto et al., 2017).

\section{Other Types}

Other types of NPs include micelles (Yohan and Chithrani, 2014), lipid-calcium-phosphate nanoparticle (Satterlee and Huang, 2016), microalgae-nanoparticle (Déniel et al., 2019), proteinbased NPs (Tarhini et al., 2017), liposomes and polymeric NPs 
TABLE 1 | The advantage and disadvantages of different types of NPs.

\begin{tabular}{|c|c|c|c|}
\hline NPs types & Advantages & Disadvantages & Application in CVD \\
\hline SPIONs & $\begin{array}{l}\text { Low toxicity, excellent biocompatibility, } \\
\text { and directional movement under the } \\
\text { external magnetic field }\end{array}$ & $\begin{array}{l}\text { SPIONs without surface modification are unstable } \\
\text { and tend to polymerize in the liquid environment; } \\
\text { remain in the body and produce images that } \\
\text { misdirect the tracer and overestimate the stem } \\
\text { cells' survival }\end{array}$ & $\begin{array}{l}\text { Cell markers, guide, and monitor the } \\
\text { therapeutic effect of stem cells on acute } \\
\text { myocardial infarction }\end{array}$ \\
\hline QDs & $\begin{array}{l}\text { Brighter and more stable fluorescence; } \\
\text { resistance to chemical and biological } \\
\text { degradation }\end{array}$ & $\begin{array}{l}\text { The high toxicity of QDs when they are using in vivo } \\
\text { systems }\end{array}$ & $\begin{array}{l}\text { Used for contrasting of blood and lymph } \\
\text { vessels; cell labeling; tumor diagnosis and } \\
\text { therapy }\end{array}$ \\
\hline SNPS & $\begin{array}{l}\text { Optical properties against ultraviolet } \\
\text { light; unique biological adaptability and } \\
\text { morphological adjustability }\end{array}$ & $\begin{array}{l}15 \mathrm{~nm} \text { diameter particles have been reported to } \\
\text { trigger more cytotoxicity than } 100 \mathrm{~nm} \text { diameter } \\
\text { particles in endothelial cells }\end{array}$ & $\begin{array}{l}\text { Have the potential in stem cell therapy including } \\
\text { stem cell differentiation, imaging, and tracking }\end{array}$ \\
\hline Metal NPs & $\begin{array}{l}\text { Excellent biocompatibility; unique } \\
\text { optical and SPR properties }\end{array}$ & Severe side effects due to its oxidation state & $\begin{array}{l}\text { AuNPs could potentialize the cardiomyocyte } \\
\text { differentiation of human pluripotent stem cells } \\
\text { and promote exosome secretion of MSCs and } \\
\text { inhibit autophagy flow of MSCs }\end{array}$ \\
\hline
\end{tabular}

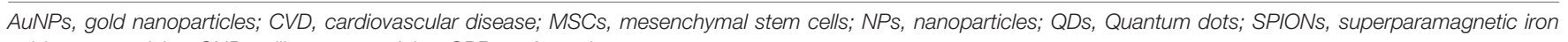
oxide nanoparticles; SNPS, silica nanoparticles; SPR, surface plasmon resonance.

(Tapeinos et al., 2017). The advantages and disadvantages of different types of NPs are shown in Table 1.

\section{STEM-BASED THERAPY WITH NPs IN CVD}

\section{NPs' Application in Cardiac Regeneration \\ NPs Deliver Genes to Stem Cells}

Previous studies have shown that genetic engineering can be used to facilitate stem cell therapy for heart disease (Hodgkinson et al., 2010; Marbán and Malliaras, 2012) by introducing therapeutic genes (proangiogenic and antiapoptotic genes) into engineered stem cells through gene vectors to prolong their survival and enhance their paracrine secretion (Deuse et al., 2009; Tang et al., 2009). Due to the immune responses and low gene volume, traditional vectors have limited applications. NP-based genes with unique biocompatibility may have higher gene delivery efficacy when transferred to stem cells, increasing cell survival and differentiation in the ischemic myocardium. Several types of nanostructured gene vectors exist. Liposomes can prevent genes from being degraded or binding nonspecifically (Pack et al., 2005; Zhang et al., 2008); polymers can increase the efficiency, reduce the cytotoxicity and improve targeting specificity (Cui et al., 2015); inorganic NPs have simple fabrication requirements, inducing low cytotoxicity (Kim and Hyeon, 2014) and can be used with blended vectors. The mechanisms of their internalization are known as endocytic pathways, including clathrin-mediated endocytosis, caveolaemediated endocytosis, and micropinocytosis and phagocytosis (Xiang et al., 2012; Calin et al., 2013). A study used chitosanalginate NPs to deliver placental growth factors in a targeted manner, which could achieve the goal of continuously releasing placental growth factors and improving cardiac function at the site of acute MI (Binsalamah et al., 2011). Another study transfected MSCs with molecularly organic-inorganic hybrid hollow mesoporous organosilica NPs with surface conjugated polyethyleneimine loaded with the hepatocyte growth factor gene and found that the paracrine activity of the hepatocyte growth factor-transfected MSCs was enhanced, which reduced the myocardial cell apoptosis and promoted angiogenesis in the rat model of MI (Zhu et al., 2016). Several studies have shown the application of different types of NPs in gene delivery (Table 2).

\section{NPs Track the Stem Cells in vivo}

As mentioned above, the fate, behavior, and survival of stem cells after transplantation in vivo remain unclear. Therefore, an efficient tool to monitor and track stem cells for long-term monitoring is necessary. SPIONs mark stem cells in three main ways: by attaching NPs to the cell surface through the internalization of NPs by the cells by through endocytosis, by receptor-mediated endocytosis, and by transfecting

TABLE 2 | NPs applications for gene delivery.

\begin{tabular}{|c|c|c|c|c|}
\hline NPs & Stem cells & Gene & Model & Model \\
\hline $\begin{array}{l}\text { Chitosan-alginate NPs } \\
\text { (Binsalamah, 2011) }\end{array}$ & - & PIGF & Ml & Rat \\
\hline Hpamam (Zhu et al., 2011) & SkMs & hVEGF-165 & Ml & Rat \\
\hline $\begin{array}{l}\text { Polyethyleneimine (Ye et al., } \\
\text { 2011) }\end{array}$ & SkMs & pHRE- VEGF & $\mathrm{Ml}$ & Rabbit \\
\hline Bac-NP (Paul et al., 2012) & hADSCs & Ang-1 & Ml & Rat \\
\hline PMSNs (Wenbin et al., 2015) & MSCs & CCR2-siRNA & $\mathrm{Ml}$ & - \\
\hline HMONs-PEl (Zhu et al., 2016) & BMMSCs & pHGF & Ml & Rat \\
\hline
\end{tabular}

Bac-NP, recombinant baculovirus complexed with a cell-penetrating transactivating transcriptional activator peptide/deoxyribonucleic acid nanoparticle; BMMSCs, bone marrow-derived mesenchymal stem cells; CCR2, C-C chemokine receptor 2; hADSCs, human adipose tissue-derived stem cells; HGF, hepatocyte growth factor; HMONs-PEl, molecularly organic-inorganic hybrid hollow mesoporous organosilica nanoparticles with surface conjugated polyethyleneimine; hPAMAM, hyperbranched polyamidoamine; Hvegf-165, human vascular endothelial growth factor-165; MI, myocardial infarction; MSCs, mesenchymal stem cells; NPS, nanoparticles; pHRE-VEGF, hypoxia-regulated vascular endothelial growth factor; PIGF, Placental growth factor; PMSNs, photoluminescent mesoporous silicon nanoparticles; SkMs, skeletal myoblasts. 
TABLE 3 | NPs applications for stem cell tracking during cardiac repair.

\begin{tabular}{|c|c|c|c|}
\hline NPs & Stem cells & Imaging modality & Model \\
\hline SNPs (Fang Chen, 2020) & hMSCs & Ultrasound imaging & In vitro \\
\hline Au@BSA@PLL (Ning et al., 2019) & hMSCs & CT & Rat \\
\hline USPIO (Mathiasen et al., 2019) & MSCs & $\mathrm{MRI}$ & IHD patients \\
\hline PANPs (Qin et al., 2018) & hESC-CMs & Photoacoustic imaging & Rat \\
\hline Iron oxide NP (Skelton et al., 2016) & hESC-CPCs & $\mathrm{MRI}$ & Pig \\
\hline PFCE-NPs (Constantinides et al., 2019) & CPCs & $\mathrm{MRI}$ & Rat \\
\hline $\mathrm{SiO}_{2}$-NPs (Gallina et al., 2015) & hMSCs & Immunofluorescence analysis of tissue slices & Rat \\
\hline
\end{tabular}

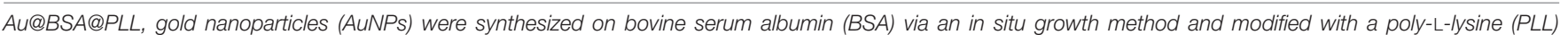

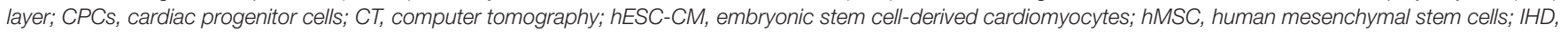

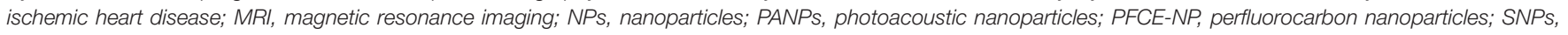
silica nanoparticles.

agent-mediated endocytosis (Frank et al., 2002). For in vivo experiments, the first approach has significant limitations, as the reticuloendothelial system recognizes and clears SPION-labeled cells (Suzuki et al., 2007; Nucci et al., 2015). However, through the internalization pathway, SPIONs can persist in the cytoplasm of stem cells where they have excellent biocompatibility. Currently, methods to enhance SPIONs transfer across membranes include increasing the electromagnetic fields to target SPIONs toward irradiated sites, ligand modifications on the surface of SPIONs to bind a receptor on the targeted cell membrane, ensuring specific SPIONs binding to the target cell, and promoting mononuclear-phagocytic cell phagocytosis of SPIONs, thus promoting passive transport (Lewin et al., 2000; Frank et al., 2002; Kraitchman et al., 2011). QDs have the potential for use in long-term monitoring in living cells, compared with traditional fluorescent probes (Ricles et al., 2011; Liu et al., 2019). Several studies have reported the feasibility of labeling stem cells through different modifications such as bioconjugated (Shah and Mao, 2011), electroporation (Sun et al., 2014), peptide delivery (Chang et al., 2008) and encapsulation and delivery by phospholipid micelles (Dubertret et al., 2002), all of which maintain the stability and safety of the label (Wang et al., 2015b). Silica dioxide NPs are applied as ultrasound contrast agents. They are usually combined with fluorescein, helium ions, or radionuclides to improve the imaging of the stem cells, thereby enabling stem cell tracking (Accomasso et al., 2012). Exosome-like silica, which has a unique morphology, provides a double-reflection interface that confers labeled stem cells with higher echogenicity and ultrasound sensitivity (Chen et al., 2017). In recent studies, different types of NPs have been applied in stem cell tracking for cardiac repair in vivo and in vitro (Table 3).

\section{NPs Enhance Stem Cell Retention After Transplantation}

Different routes of stem cell administration include intracoronary (Vulliet et al., 2004; Liu et al., 2016; Vilahur et al., 2017), transendocadial method (Amado et al., 2005), systemic method (Barbash et al., 2003), and intravenous method (Kulandavelu et al., 2016). Extremely low cell retention after transplantation is the most critical barrier to the application of stem cell therapy for cardiac repair. As much as $1.5 \%$ of transplanted stem cells accumulated in the myocardium after only $2 \mathrm{~h}$ (Al Kindi et al., 2008). NPs may be a potential approach to address this problem. It has been demonstrated that NPs can enhance stem cell retention by providing a cardiac-specific extracellular matrix (ECM) environment (include impacts some signal pathway), affecting the focal adhesion complex of myocardial MSCs (Bejleri et al., 2018), promoting the interactions with cardiomyocytes and affecting lysosomal function in ischemic environments (Popara et al., 2018). Magnetic NPs seem to resolve this accumulation to some extent. This ameliorating effect may be associated with the magnetic field, and the retention of SPION-labeled stem cells may be significantly enhanced. The SPIONs can be applied not only for tracking stem cells but also for studying other aspects in a magnetic field. The advantage of magneto-electroporation in the delivery of cardiac stem cells is that it reduces the incubation time needed for NPs to label the cells markers (Calin et al., 2013). A study found that using SPION-labeled MSCs in the presence of a magnetic field might enhance cell homing of MSCs at the site of injury and contribute to the improvement of cardiac function and attenuation of injury after heart failure (Naseroleslami et al., 2018). The recruitment and leaching of Ly6Chigh mononuclear cells in the ischemic heart were associated with the signal transduction of the chemokine ligand 2/chemokine receptor 2 (CCR2), which was required to control pro-inflammatory monocytes and enhance the inflammatory microenvironment that adversely affects MSCs transplantation. A study applied photoluminescent porous SNPs and MSCs loaded with silencing CCR2 for the treatment of ischemic myocardial injury (Lu et al., 2015). The silencing CCR2 moiety targeted the expression of CCR2 in Ly6Chigh inflammatory monocytes, reducing the accumulation of these cells during infarction, thereby enhancing the efficacy of MSC transplantation and myocardial remodeling. Figure 1 shows the mechanisms of NPs combined with stem cells and applied for cardiac regeneration.

\section{NPs' Application in Peripheral Vascular Regeneration}

NPs Facilitate the Proangiogenic Effect of Stem Cells

The advantages of cell-based therapy with NPs have been proven in many practices. For example, MSCs have been demonstrated to augment collateral perfusion through paracrine mechanisms (Kinnaird et al., 2004). Compared with the use of proangiogenic 


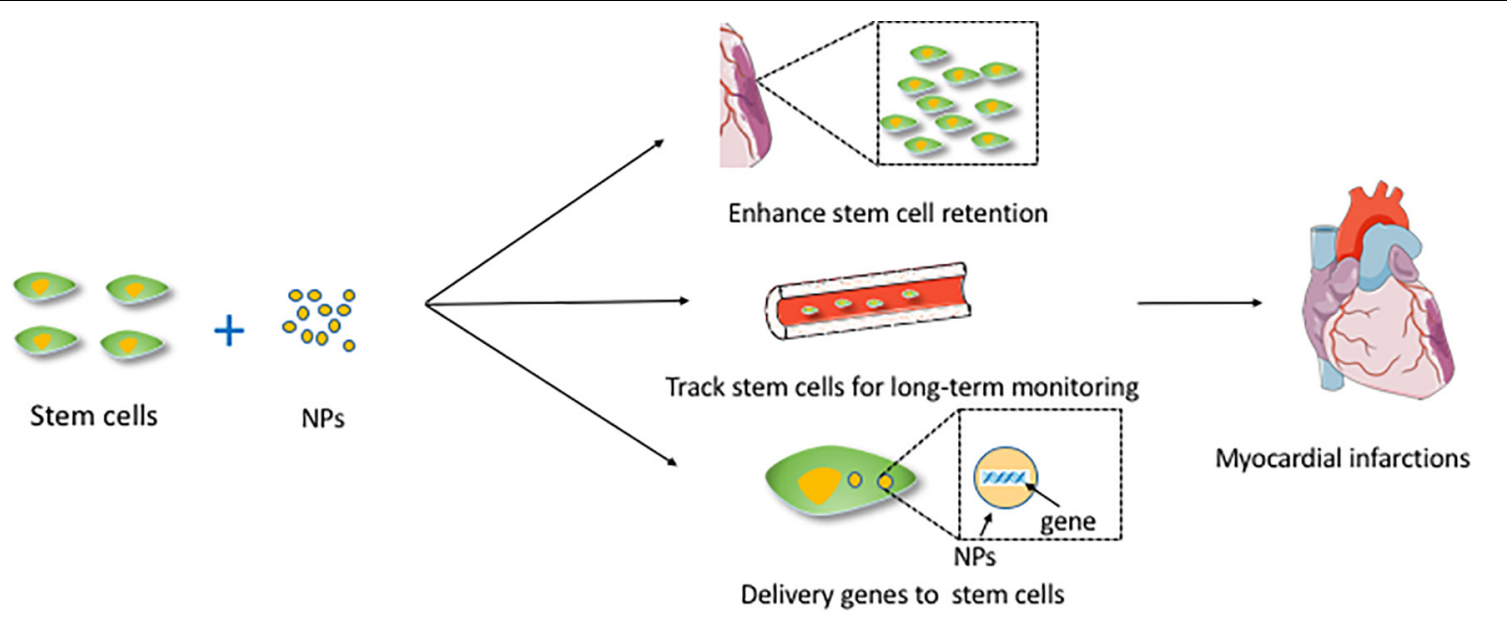

FIGURE 1 | The mechanisms of NPs combined with stem cells and applied for cardiac regeneration. This figure sets an example of NPs used in myocardial infarctions. NPs, nanoparticles.

TABLE 4 | NPs applications for promoting stem cells to secrete factors related to angiogenesis.

\begin{tabular}{|c|c|c|c|}
\hline NPs & Stem cells & Relative factors & Model \\
\hline Magnetic NPs (Ishii et al., 2011) & hMSCs & VEGF & Nude mouse \\
\hline AuNPs (Chen et al., 2018) & MSCs & CD31, $\alpha-S M A$ & In vitro \\
\hline Cerium oxide NPs (Das et al., 2012) & HUVECS & VEGF, HIF- $1 \alpha$ & In vitro \\
\hline ZnO NPs (Augustine et al., 2014; Ahtzaz et al., 2017) & HUVECS & VEGF, FGF2 & In vitro \\
\hline
\end{tabular}

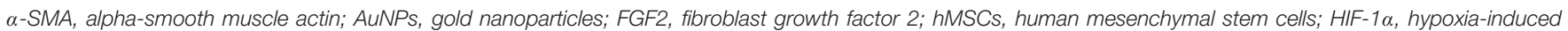

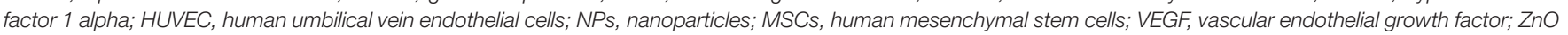
NPs, zinc oxide nanoparticles.

factors alone, the efficiency of induced angiogenesis was more stable and lasted longer with a combination of stem cells and NPs. Recently, a study proposed that tethering the adiposederived stem cells (ADSCs) surface with NPs releasing tumor necrosis factor $\alpha$, also named nanostimulators, stimulated cellular secretory activity in situ, and the results showed that ADSCs with tethered nanostimulators promoted vascularization in a 3D microvascular chip and enhanced the recovery of cell perfusion, animal walking and muscle mass in murine ischemic hind limbs compared to the effect of untreated ADSCs (Leong et al., 2020). Another study has proven that human MSCs incubated with magnetic NP-containing liposomes showed increased expression of vascular endothelial growth factor (VEGF) and a reduced apoptosis rate in unilateral hind limb ischemic animal models compared to these effects in the control group (Ishii et al., 2011). Similarly, a study showed that chitosan oligosaccharide/heparin NPs had a high cytokine-loading capacity and allowed cytokines to maintain stable bioactivity longer in an environment at physiological $\mathrm{pH}$ in vitro (Wang et al., 2015a). In recent years, metal nanomaterials have offered the potential to improve the efficiency of vascular regeneration. A study in 2004 firstly proved that AuNPs have angiogenesis properties. The plausible mechanism could be that controlled reactive oxygen species generation and consequently reduced redox signaling (Nethi et al., 2014). A similar mechanism was proven in the treatment of hepatic ischemia-reperfusion using ceria NPs (Ni et al., 2019). Later, another study indicated that VEGF on fibronectin-incorporated AuNPs promoted MSCs migration through the endothelial oxide synthase/metalloproteinase signaling pathway, which promoted MSC proliferation and increased the biocompatibility of the particle (Chen et al., 2018). Table 4 shows NPs applications in promoting stem cells to secrete factors related to angiogenesis.

\section{NPs Mimic the ECM Environment}

Extracellular matrix is a complex environment that plays a role in maintaining cell and tissue structure and function (Rosso et al., 2004), and its components and three-dimensional ultrastructure transmit specific signals to cells (Sorokin, 2010). Nanomaterials used for tissue engineering have been proposed to mimic ECM. A previous experiment described the development of hyaluronan oligomers-loaded poly NPs used for the targeted, controlled, and sustained delivery of hyaluronan oligomers for the elastogenic induction of aneurysms in aortic smooth muscle cells in rat models (Sylvester et al., 2013). The ECM is a polymerbased microenvironment that serves as a pool for signaling molecules (Afratis et al., 2012; Mecham, 2012). EPCs are ideal for use in inducing primary endothelial cells for vascular tissue engineering (Hung et al., 2009a). EPCs migration and homing to ischemic tissues are mediated by cell adhesion molecules and chemokines (Landmesser et al., 2004). Stromal-derived factor $1 \alpha(\mathrm{SDF}-1 \alpha)$ and its receptor $\mathrm{C}-\mathrm{X}-\mathrm{C}$ motif chemokine receptor 
Stem cells

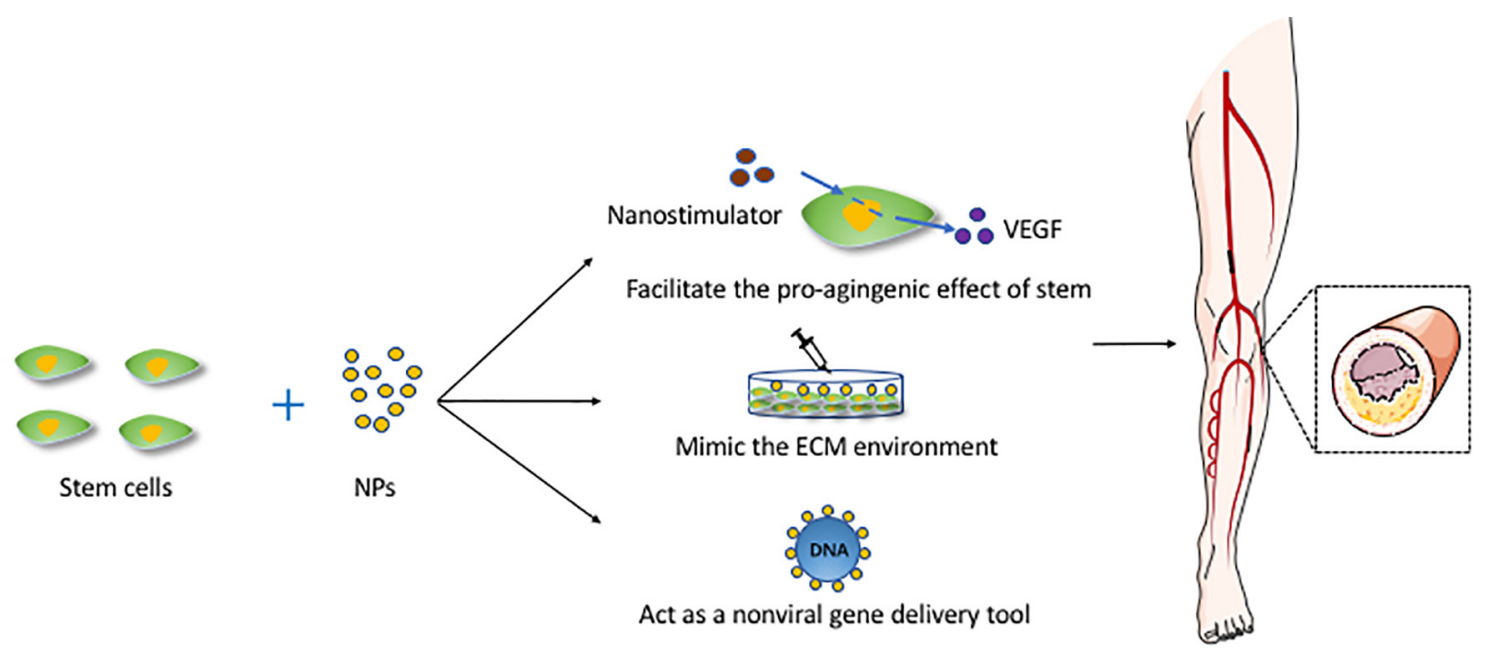

FIGURE 2 | The mechanisms of NPs combined with stem cells and applied for vascular regeneration. This figure sets an example of NPs used in artery atherosclerosis. ECM, extracellular matrix; NPs, nanoparticles; VEGF, vascular endothelial growth factor.

(CXCR4) are essential molecules that direct cell migration. A study has demonstrated that collagen combined with AuNPs nanocomposites may accelerate the proliferation and migration of MSCs and stimulate endothelial cell differentiation to facilitate vascular regeneration (Hung et al., 2014a). Another study showed that EPC-seeded mixtures of polyurethane (PU, which might be produced to individual match the microenvironment of vascular tissue precisely) and Au-NPs differentiate into endothelial cells in vitro, and the enhanced maturation of the EPCs with the nanocomposites of PU-Au-NPs was more remarkable, probably because of the SDF-1 $\alpha /$ CXCR4 signaling pathway in vitro. Furthermore, other experiments showed that EPCs seeded on PU-Au-coated catheters effectively reduced thrombosis by differentiating into endothelial cells in vivo (Hung et al., 2014b). However, no clinical trials have explored whether this kind of therapy would have a favorable effect on PVD patients.

\section{NPs Act as a Non-viral Gene Delivery Tool}

Adipose-derived stromal cell populations contain MSCs (Zuk et al., 2001), which shows the potential to release VEGF, and upregulating VEGF has been proved to enhance therapeutic angiogenesis (Rehman et al., 2004; Cao et al., 2005). Currently, most gene therapies for PVD are based on the use of viral vectors, which always raises safety concerns (Hacein-Bey-Abina et al., 2008; Keeney et al., 2013). In recent years, some studies have begun to focus on nanomaterials, which can act as non-viral gene delivery tools and enhance the transfection efficiency at the time (Green et al., 2008; Yang et al., 2009). One study demonstrated the use of NPs to transfect stem cells in vitro and suggested methods for validating the efficacy of using VEGF-expressing stem cells to promote angiogenesis in a murine ischemic hind limb model (Keeney et al., 2013). Another study indicated that CXCR4 is expressed on progenitor and inflammatory cells, facilitating cell migration toward ischemic tissues where they participate in revascularization and tissue repair. The result of this study showed that NP-induced CXCR4 overexpression may promote favorable phenotypic changes in and the therapeutic efficacy of stem cells in response to an ischemic environment in a murine model of peripheral arterial disease (Deveza et al., 2016). In addition, nanocapsules constitute a universal and highly efficient biomimetic platform for the transfer of genetic material. A recent study showed that calcium carbonate NPs, upon entering the MSCs, will modulate the local intracellular $\mathrm{pH}$, leading to a delay in the degradation of the layers, and hampering the release of functional RNA molecules, which led to a decrease in delivery efficiency and indicated their higher stability (Tarakanchikova et al., 2020). Figure 2 shows the mechanisms of NPs combined with stem cells and applied for vascular regeneration.

\section{THE LIMITATIONS AND FUTURE DIRECTION OF NPS FOR CVD THERAPY}

The main problem with NPs is their toxicity, including cellular toxicity and tissue toxicity. As the size of NPs decreases, the surface area increases, leading to a dose-dependent increase in the oxidation and DNA destruction capacity of the nanomaterials (Risom et al., 2005). NPs with a high aspect ratio have the greatest toxicity (Hsiao and Huang, 2011). Also, higher cationic charges cause severe toxicity because of hemolysis and platelet aggregation (Gatoo et al., 2014). Approaches such as arginine-glycine-aspartic acid peptide conjugation have been attempted. High-performance arginine-glycine-aspartic acidconjugated dendrimer-modified gold nanorods exhibited great potential in applications, such as tumor targeting, imaging, and selective photothermal therapy (Li et al., 2010). In the future, these nanoprobes may be applied for use in CVD therapy.

Limited knowledge regarding the fate of these NPs and the extent of their accumulation in internal organs creates another bottleneck in the efforts for determining the potential side effect of their accumulation in the body. For example, when stem cells die, SPIONs remain in the body and produce 
images that misdirect the tracer and overestimate the extent of stem cell survival. QDs may impact the behavior of stem cells, leading to unexpected results. For example, stem cells labeled with QDs exhibited alterations and abnormality (Hsieh et al., 2006). Controlled and smart liberation of nanomaterials or their functional moieties and subsequent activation of the angiogenic signaling cascade in a spatiotemporal manner is exceptionally critical for positive therapeutic angiogenic outcomes.

Despite the various developments in tissue engineering, the challenges to developing fully functional vascularized tissue that recapitulates the complexities of the native tissue remain. The mechanisms of angiogenesis, the role of the scaffold architecture, and the interaction of potential biological and inorganic cues with the developing vasculature are among the key parameters to be considered as research progresses to a higher level. Efforts should be taken to enhance capillary network infiltration without compromising the physical and mechanical characteristics of the scaffolds (Patel and Lee, 2015). Besides, the potential accumulation of NPs in the liver and kidneys and whether such accumulation increases organ damage must be ascertained. In future studies, the mechanisms of stem cell-based cardiac and vascular regeneration need to be more comprehensively understood. Further studies are also needed for in-depth exploration of the possible effects of NPs parameters such as size, charge, morphology, surface characteristics (Carlander et al., 2018), as well as their absorption, distribution, and metabolic mechanisms in vivo (Carlander et al., 2016).

Compared with traditional treatments, NPs have shown potential superiority for use in therapy. Their particular chemical and physical advantages influence stem cell activity, such as through their use as non-viral gene delivery tools. As gene therapy for CVD has become increasingly popular, NPs applications are promising. In tumor therapy, smart micro/nanoparticles (MNPs) can react in a predictable and

\section{REFERENCES}

Accomasso, L., Cibrario Rocchietti, E., Raimondo, S., Catalano, F., Alberto, G., Giannitti, A., et al. (2012). Fluorescent silica nanoparticles improve optical imaging of stem cells allowing direct discrimination between live and earlystage apoptotic cells. Small 8, 3192-3200. doi: 10.1002/smll.201200882

Afratis, N., Gialeli, C., Nikitovic, D., Tsegenidis, T., Karousou, E., Theocharis, A. D., et al. (2012). Glycosaminoglycans: key players in cancer cell biology and treatment. FEBS J. 279, 1177-1197. doi: 10.1111/j.1742-4658.2012.08529.x

Ahtzaz, S., Nasir, M., Shahzadi, L., Amir, W., Anjum, A., Arshad, R., et al. (2017). A study on the effect of zinc oxide and zinc peroxide nanoparticles to enhance angiogenesis-pro-angiogenic grafts for tissue regeneration applications. Mater. Des. 132, 409-418. doi: 10.1016/j.matdes.2017.07.023

Aillon, K. L., Xie, Y., El-Gendy, N., Berkland, C. J., and Forrest, M. L. (2009). Effects of nanomaterial physicochemical properties on in vivo toxicity. Adv. Drug Deliv. Rev. 61, 457-466. doi: 10.1016/j.addr.2009.03.010

Al Kindi, A., Ge, Y., Shum-Tim, D., and Chiu, R. C. (2008). Cellular cardiomyoplasty: routes of cell delivery and retention. Front. Biosci. 13, 24212434. doi: $10.2741 / 2855$

Alcor, D., Gouzer, G., and Triller, A. (2009). Single-particle tracking methods for the study of membrane receptors dynamics. Eur. J. Neurosci. 30, 987-997. doi: 10.1111/j.1460-9568.2009.06927.x

Amado, L. C., Saliaris, A. P., Schuleri, K. H., St John, M., Xie, J. S., Cattaneo, S., et al. (2005). Cardiac repair with intramyocardial injection of allogeneic specific manner to external/internal stimuli. These MNPs including $\mathrm{pH}$-sensitive peptides and polymers, redox-responsive micelles and nanogels, Thermo- and magnetic-responsive NPs, mechanical- and electrical-responsive MNPs, light- and ultrasound-sensitive particles. Multiresponsive MNPs include dual stimuli-sensitive nanosheets of graphene (Karimi et al., 2016), which have been rarely applied in stem cell-based CVD therapy.

\section{CONCLUSION}

NPs might have significant potential uses in human treatments in the future, thereby meeting the changing needs of individual patients worldwide.

\section{AUTHOR CONTRIBUTIONS}

ZL provided the topic of this review and revised the manuscript. YS and YL wrote and contributed equally to the manuscript. LY helped in correcting the logic and some details of the manuscript. All the authors read and approved the final manuscript.

\section{FUNDING}

This work was supported by the National Natural Science Foundation of China (Grant Nos. 81300236, 81670433, and 81970398), the Project of Zhejiang Medical Young Talents 2017 (Grant No. 2019-03-01), Zhejiang Medical and Health Science and Technology Project (Grant No. 2020RC014), and the Natural Science Foundation of Zhejiang Province (Grant No. LQ20H020008).

mesenchymal stem cells after myocardial infarction. Proc. Natl. Acad. Sci. U.S.A. 102, 11474-11479. doi: 10.1073/pnas.0504388102

Arslan, F., Lai, R. C., Smeets, M. B., Akeroyd, L., Choo, A., Aguor, E. N., et al. (2013). Mesenchymal stem cell-derived exosomes increase ATP levels, decrease oxidative stress and activate PI3K/Akt pathway to enhance myocardial viability and prevent adverse remodeling after myocardial ischemia/reperfusion injury. Stem Cell Res. 10, 301-312. doi: 10.1016/j.scr.2013.01.002

Asahara, T., Murohara, T., Sullivan, A., Silver, M., van der Zee, R., Li, T., et al. (1997). Isolation of putative progenitor endothelial cells for angiogenesis. Science 275, 964-967. doi: 10.1126/science.275.5302.964

Augustine, R., Dominic, E. A., Reju, I., Kaimal, B., Kalarikkal, N., and Thomas, S. (2014). Investigation of angiogenesis and its mechanism using zinc oxide nanoparticle-loaded electrospun tissue engineering scaffolds. RSC Adv. 4, 51528-51536. doi: 10.1039/C4RA7361D

Barbash, I. M., Chouraqui, P., Baron, J., Feinberg, M. S., Etzion, S., Tessone, A., et al. (2003). Systemic delivery of bone marrow-derived mesenchymal stem cells to the infarcted myocardium: feasibility, cell migration, and body distribution. Circulation 108, 863-868. doi: 10.1161/01.cir.0000084828.50310.6a

Bartolo, E., Thorne, C. S., Gatt, A., and Formosa, C. (2019). The influence of peripheral arterial disease on lower limb surface myoelectric signals in patients living with type II diabetes mellitus. Gait Posture 73, 228-232. doi: 10.1016/j. gaitpost.2019.07.254

Bayda, S., Adeel, M., Tuccinardi, T., Cordani, M., and Rizzolio, F. (2019). The history of nanoscience and nanotechnology: from chemical-physical 
applications to nanomedicine. Molecules 25:112. doi: $10.3390 /$ molecules 25010112

Bejleri, D., Streeter, B. W., Nachlas, A. L. Y., Brown, M. E., Gaetani, R., Christman, K. L., et al. (2018). A bioprinted cardiac patch composed of cardiac-specific extracellular matrix and progenitor cells for heart repair. Adv. Healthc. Mater. 7:e1800672. doi: 10.1002/adhm.201800672

Binsalamah, Z. M. (2011). Intramyocardia sustained delivery of placental growth factor using nanoparticles as a vehicle for delivery in the rat infarct model. Int. J. Nanomed. 6, 2667-2678. doi: 10.2147/IJN.S25175

Binsalamah, Z. M., Paul, A., Khan, A. A., Prakash, S., and Shum-Tim, D. (2011). Intramyocardial sustained delivery of placental growth factor using nanoparticles as a vehicle for delivery in the rat infarct model. Int. J. Nanomed. 6, 2667-2678. doi: 10.2147/ijn.s25175

Botto, C., Mauro, N., Amore, E., Martorana, E., Giammona, G., and Bondi, M. L. (2017). Surfactant effect on the physicochemical characteristics of cationic solid lipid nanoparticles. Int. J. Pharm. 516, 334-341. doi: 10.1016/j.ijpharm.2016.11. 052

Boyer, M., Townsend, L. E., Vogel, L. M., Falk, J., Reitz-Vick, D., Trevor, K. T., et al. (2000). Isolation of endothelial cells and their progenitor cells from human peripheral blood. J. Vasc. Surg. 31, 181-189. doi: 10.1016/s0741-5214(00) 70080-2

Bull, E., Madani, S. Y., Sheth, R., Seifalian, A., Green, M., and Seifalian, A. M. (2014). Stem cell tracking using iron oxide nanoparticles. Int. J. Nanomed. 9, 1641-1653. doi: 10.2147/ijn.s48979

Calin, M., Stan, D., and Simion, V. (2013). Stem cell regenerative potential combined with nanotechnology and tissue engineering for myocardial regeneration. Curr. Stem Cell Res. Ther. 8, 292-303. doi: 10.2174/1574888x 11308040005

Cao, Y., Sun, Z., Liao, L., Meng, Y., Han, Q., and Zhao, R. C. (2005). Human adipose tissue-derived stem cells differentiate into endothelial cells in vitro and improve postnatal neovascularization in vivo. Biochem. Biophys. Res. Commun. 332, 370-379. doi: 10.1016/j.bbrc.2005.04.135

Carlander, U., Li, D., Jolliet, O., Emond, C., and Johanson, G. (2016). Toward a general physiologically-based pharmacokinetic model for intravenously injected nanoparticles. Int. J. Nanomed. 11, 625-640. doi: 10.2147/ijn.s94370

Carlander, U., Moto, T. P., Desalegn, A. A., Yokel, R. A., and Johanson, G. (2018). Physiologically based pharmacokinetic modeling of nanoceria systemic distribution in rats suggests dose- and route-dependent biokinetics. Int. J. Nanomed. 13, 2631-2646. doi: 10.2147/ijn.s157210

Chang, J. C., Su, H. L., and Hsu, S. H. (2008). The use of peptide-delivery to protect human adipose-derived adult stem cells from damage caused by the internalization of quantum dots. Biomaterials 29, 925-936. doi: 10.1016/j. biomaterials.2007.10.046

Chauhan, H., Mohapatra, S., Munt, D. J., Chandratre, S., and Dash, A. (2016). Physical-chemical characterization and formulation considerations for solid lipid nanoparticles. AAPS PharmSciTech 17, 640-651. doi: 10.1208/s12249-0150394-x

Chen, F., Du, Y., Esposito, E., Liu, Y., Guo, S., Wang, X., et al. (2015). Effects of focal cerebral ischemia on exosomal versus serum miR126. Transl. Stroke Res. 6, 478-484. doi: 10.1007/s12975-015-0429-3

Chen, F., Ma, M., Wang, J., Wang, F., Chern, S. X., Zhao, E. R., et al. (2017). Exosome-like silica nanoparticles: a novel ultrasound contrast agent for stem cell imaging. Nanoscale 9, 402-411. doi: 10.1039/c6nr08177k

Chen, Y. W., Hsieh, S. C., Yang, Y. C., Hsu, S. H., Kung, M. L., Lin, P. Y., et al. (2018). Functional engineered mesenchymal stem cells with fibronectin-gold composite coated catheters for vascular tissue regeneration. Nanomedicine 14, 699-711. doi: 10.1016/j.nano.2017.12.023

Collaborators, G. D. A. H. (2018). Global, regional, and national disability-adjusted life-years (DALYs) for 359 diseases and injuries and healthy life expectancy (HALE) for 195 countries and territories, 1990-2017: a systematic analysis for the Global Burden of Disease Study 2017. Lancet 392, 1859-1922. doi: 10.1016/ s0140-6736(18)32335-3

Constantinides, C., McNeill, E., Carnicer, R., Al Haj Zen, A., Sainz-Urruela, R., Shaw, A., et al. (2019). Improved cellular uptake of perfluorocarbon nanoparticles for in vivo murine cardiac (19)F MRS/MRI and temporal tracking of progenitor cells. Nanomedicine 18, 391-401. doi: 10.1016/j.nano.2018. 10.014
Cromer Berman, S. M., Walczak, P., and Bulte, J. W. (2011). Tracking stem cells using magnetic nanoparticles. Wiley Interdiscip. Rev. Nanomed. Nanobiotechnol. 3, 343-355. doi: 10.1002/wnan.140

Cui, Z. K., Fan, J., Kim, S., Bezouglaia, O., Fartash, A., Wu, B. M., et al. (2015). Delivery of siRNA via cationic Sterosomes to enhance osteogenic differentiation of mesenchymal stem cells. J. Control. Release 217, 42-52. doi: 10.1016/j.jconrel. 2015.08.031

Das, S., Singh, S., Dowding, J. M., Oommen, S., Kumar, A., Sayle, T. X., et al. (2012). The induction of angiogenesis by cerium oxide nanoparticles through the modulation of oxygen in intracellular environments. Biomaterials 33, 77467755. doi: 10.1016/j.biomaterials.2012.07.019

Déniel, M., Errien, N., Daniel, P., Caruso, A., and Lagarde, F. (2019). Current methods to monitor microalgae-nanoparticle interaction and associated effects. Aquat. Toxicol. 217:105311. doi: 10.1016/j.aquatox.2019.105311

Deuse, T., Peter, C., Fedak, P. W., Doyle, T., Reichenspurner, H., Zimmermann, W. H., et al. (2009). Hepatocyte growth factor or vascular endothelial growth factor gene transfer maximizes mesenchymal stem cell-based myocardial salvage after acute myocardial infarction. Circulation 120, S247-S254. doi: 10. 1161/circulationaha.108.843680

Deveza, L., Choi, J., Lee, J., Huang, N., Cooke, J., and Yang, F. (2016). Polymer-DNA nanoparticle-induced CXCR4 overexpression improves stem cell engraftment and tissue regeneration in a mouse Hindlimb Ischemia model. Theranostics 6, 1176-1189. doi: 10.7150/thno.12866

Dubertret, B., Skourides, P., Norris, D. J., Noireaux, V., Brivanlou, A. H., and Libchaber, A. (2002). In vivo imaging of quantum dots encapsulated in phospholipid micelles. Science 298, 1759-1762. doi: 10.1126/science.1077194

Fang Chen, J. V. J. (2020). Cell Tracking: Methods and Protocols. Boston, MA: Springer.

Frank, J. A., Zywicke, H., Jordan, E. K., Mitchell, J., Lewis, B. K., Miller, B., et al. (2002). Magnetic intracellular labeling of mammalian cells by combining (FDAapproved) superparamagnetic iron oxide MR contrast agents and commonly used transfection agents. Acad. Radiol. 9(Suppl. 2), S484-S487. doi: 10.1016/ s1076-6332(03)80271-4

Gallina, C., Capeloa, T., Saviozzi, S., Accomasso, L., Catalano, F., Tullio, F., et al. (2015). Human mesenchymal stem cells labelled with dye-loaded amorphous silica nanoparticles: long-term biosafety, stemness preservation and traceability in the beating heart. J. Nanobiotechnol. 13:77. doi: 10.1186/s12951-015-01411

Gasco, M. R. (2007). Lipid nanoparticles: perspectives and challenges. Adv. Drug Deliv. Rev. 59, 377-378. doi: 10.1016/j.addr.2007.05.004

Gatoo, M. A., Naseem, S., Arfat, M. Y., Dar, A. M., Qasim, K., and Zubair, S. (2014). Physicochemical properties of nanomaterials: implication in associated toxic manifestations. Biomed Res. Int. 2014:498420. doi: 10.1155/2014/498420

Georgieva, J. V., Kalicharan, D., Couraud, P. O., Romero, I. A., Weksler, B., Hoekstra, D., et al. (2011). Surface characteristics of nanoparticles determine their intracellular fate in and processing by human blood-brain barrier endothelial cells in vitro. Mol. Ther. 19, 318-325. doi: 10.1038/mt.2010.236

Green, J. J., Langer, R., and Anderson, D. G. (2008). A combinatorial polymer library approach yields insight into non-viral gene delivery. Acc. Chem. Res. 41, 749-759. doi: 10.1021/ar7002336

Hacein-Bey-Abina, S., Garrigue, A., Wang, G. P., Soulier, J., Lim, A., Morillon, E., et al. (2008). Insertional oncogenesis in 4 patients after retrovirus-mediated gene therapy of SCID-X1. J. Clin. Invest. 118, 3132-3142. doi: 10.1172/jci35700

Hare, J. M., DiFede, D. L., Rieger, A. C., Florea, V., Landin, A. M., El-Khorazaty, J., et al. (2017). Randomized comparison of allogeneic versus autologous mesenchymal stem cells for nonischemic dilated cardiomyopathy: POSEIDONDCM trial. J. Am. Coll. Cardiol. 69, 526-537. doi: 10.1016/j.jacc.2016.11.009

Hare, J. M., Traverse, J. H., Henry, T. D., Dib, N., Strumpf, R. K., Schulman, S. P., et al. (2009). A randomized, double-blind, placebo-controlled, dose-escalation study of intravenous adult human mesenchymal stem cells (prochymal) after acute myocardial infarction. J. Am. Coll. Cardiol. 54, 2277-2286. doi: 10.1016/j. jacc.2009.06.055

Hedhli, J., Konopka, C. J., Schuh, S., Bouvin, H., Cole, J. A., Huntsman, H. D., et al. (2017). Multimodal assessment of mesenchymal stem cell therapy for diabetic vascular complications. Theranostics 7, 3876-3888. doi: 10.7150/thno.19547

Hodgkinson, C. P., Gomez, J. A., Mirotsou, M., and Dzau, V. J. (2010). Genetic engineering of mesenchymal stem cells and its application in human disease therapy. Hum. Gene Ther. 21, 1513-1526. doi: 10.1089/hum.2010.165 
Hsiao, I. L., and Huang, Y. J. (2011). Effects of various physicochemical characteristics on the toxicities of $\mathrm{ZnO}$ and $\mathrm{TiO}$ nanoparticles toward human lung epithelial cells. Sci. Total Environ. 409, 1219-1228. doi: 10.1016/j.scitotenv. 2010.12.033

Hsieh, S. C., Wang, F. F., Lin, C. S., Chen, Y. J., Hung, S. C., and Wang, Y. J. (2006). The inhibition of osteogenesis with human bone marrow mesenchymal stem cells by CdSe/ZnS quantum dot labels. Biomaterials 27, 1656-1664. doi: 10.1016/j.biomaterials.2005.09.004

Hung, H. S., Chang, C. H., Chang, C. J., Tang, C. M., Kao, W. C., Lin, S. Z., et al. (2014a). In vitro study of a novel nanogold-collagen composite to enhance the mesenchymal stem cell behavior for vascular regeneration. PLoS One 9:e104019. doi: 10.1371/journal.pone.0104019

Hung, H. S., Yang, Y. C., Lin, Y. C., Lin, S. Z., Kao, W. C., Hsieh, H. H., et al. (2014b). Regulation of human endothelial progenitor cell maturation by polyurethane nanocomposites. Biomaterials 35, 6810-6821. doi: 10.1016/j. biomaterials.2014.04.076

Hung, H. S., Chu, M. Y., Lin, C. H., Wu, C. C., and Hsu, S. H. (2012). Mediation of the migration of endothelial cells and fibroblasts on polyurethane nanocomposites by the activation of integrin-focal adhesion kinase signaling. J. Biomed. Mater. Res. A 100, 26-37. doi: 10.1002/jbm.a.33224

Hung, H. S., Shyu, W. C., Tsai, C. H., Hsu, S. H., and Lin, S. Z. (2009a). Transplantation of endothelial progenitor cells as therapeutics for cardiovascular diseases. Cell Transplant. 18, 1003-1012. doi: 10.3727/ 096368909x12483162196683

Hung, H. S., Wu, C. C., Chien, S., and Hsu, S. H. (2009b). The behavior of endothelial cells on polyurethane nanocomposites and the associated signaling pathways. Biomaterials 30, 1502-1511. doi: 10.1016/j.biomaterials.2008.12.003

Iravani, S., Korbekandi, H., Mirmohammadi, S. V., and Zolfaghari, B. (2014). Synthesis of silver nanoparticles: chemical, physical and biological methods. Res. Pharm. Sci. 9, 385-406.

Ishii, M., Shibata, R., Numaguchi, Y., Kito, T., Suzuki, H., Shimizu, K., et al. (2011). Enhanced angiogenesis by transplantation of mesenchymal stem cell sheet created by a novel magnetic tissue engineering method. Arterioscler Thromb. Vasc. Biol. 31, 2210-2215. doi: 10.1161/atvbaha.111.231100

Jung, D., Minami, I., Patel, S., Lee, J., Jiang, B., Yuan, Q., et al. (2012). Incorporation of functionalized gold nanoparticles into nanofibers for enhanced attachment and differentiation of mammalian cells. J. Nanobiotechnol. 10:23. doi: 10.1186/ 1477-3155-10-23

Kandi, V., and Kandi, S. (2015). Antimicrobial properties of nanomolecules: potential candidates as antibiotics in the era of multi-drug resistance. Epidemiol. Health 37:e2015020. doi: 10.4178/epih/e2015020

Karimi, M., Ghasemi, A., Sahandi Zangabad, P., Rahighi, R., Moosavi Basri, S. M., Mirshekari, H., et al. (2016). Smart micro/nanoparticles in stimulusresponsive drug/gene delivery systems. Chem. Soc. Rev. 45, 1457-1501. doi: $10.1039 / \mathrm{c} 5 \mathrm{cs} 00798 \mathrm{~d}$

Keeney, M., Deveza, L., and Yang, F. (2013). Programming stem cells for therapeutic angiogenesis using biodegradable polymeric nanoparticles. J. Vis. Exp. 79:e50736. doi: 10.3791/50736

Kim, S. T., Chompoosor, A., Yeh, Y. C., Agasti, S. S., Solfiell, D. J., and Rotello, V. M. (2012). Dendronized gold nanoparticles for siRNA delivery. Small 8, 3253-3256. doi: 10.1002/smll.201201141

Kim, T., and Hyeon, T. (2014). Applications of inorganic nanoparticles as therapeutic agents. Nanotechnology 25:012001. doi: 10.1088/0957-4484/25/1/ 012001

Kinnaird, T., Stabile, E., Burnett, M. S., Shou, M., Lee, C. W., Barr, S., et al. (2004). Local delivery of marrow-derived stromal cells augments collateral perfusion through paracrine mechanisms. Circulation 109, 1543-1549. doi: 10.1161/01. cir.0000124062.31102.57

Kraitchman, D. L., Kedziorek, D. A., and Bulte, J. W. (2011). MR imaging of transplanted stem cells in myocardial infarction. Methods Mol. Biol. 680, 141152. doi: 10.1007/978-1-60761-901-7_10

Kulandavelu, S., Karantalis, V., Fritsch, J., Hatzistergos, K. E., Loescher, V. Y., McCall, F., et al. (2016). Pim1 kinase overexpression enhances ckit(+) cardiac stem cell cardiac repair following myocardial infarction in swine. J. Am. Coll. Cardiol. 68, 2454-2464. doi: 10.1016/j.jacc.2016.09.925

La Francesca, S. (2012). Nanotechnology and stem cell therapy for cardiovascular diseases: potential applications. Methodist Debakey Cardiovasc. J. 8, 28-35. doi: $10.14797 / \mathrm{mdcj}-8-1-28$
Landmesser, U., Engberding, N., Bahlmann, F. H., Schaefer, A., Wiencke, A., Heineke, A., et al. (2004). Statin-induced improvement of endothelial progenitor cell mobilization, myocardial neovascularization, left ventricular function, and survival after experimental myocardial infarction requires endothelial nitric oxide synthase. Circulation 110, 1933-1939. doi: 10.1161/01. cir.0000143232.67642.7a

Lasala, G. P., Silva, J. A., and Minguell, J. J. (2012). Therapeutic angiogenesis in patients with severe limb ischemia by transplantation of a combination stem cell product. J. Thorac. Cardiovasc. Surg. 144, 377-382. doi: 10.1016/j.jtcvs.2011. 08.053

Le, N. D. B., Hou, S., Tonga, G. Y., Jerri, H. A., Elci, S. G., Mizuhara, T., et al. (2017). Nanoparticle probes for quantifying supramolecular determinants of biosurface affinity. Part. Part. Syst. Charact. 34:1700100. doi: 10.1002/ppsc.201700100

Lee, H. C., An, S. G., Lee, H. W., Park, J. S., Cha, K. S., Hong, T. J., et al. (2012). Safety and effect of adipose tissue-derived stem cell implantation in patients with critical limb ischemia: a pilot study. Circ. J. 76, 1750-1760. doi: 10.1253/ circj.cj-11-1135

Lee, M. K., Lim, S. J., and Kim, C. K. (2007). Preparation, characterization and in vitro cytotoxicity of paclitaxel-loaded sterically stabilized solid lipid nanoparticles. Biomaterials 28, 2137-2146. doi: 10.1016/j.biomaterials.2007.01. 014

Lei, Y., Tang, H., Yao, L., Yu, R., Feng, M., and Zou, B. (2008). Applications of mesenchymal stem cells labeled with Tat peptide conjugated quantum dots to cell tracking in mouse body. Bioconjug. Chem. 19, 421-427. doi: 10.1021/ bc0700685

Leong, J., Hong, Y. T., Wu, Y. F., Ko, E., Dvoretskiy, S., Teo, J. Y., et al. (2020). Surface tethering of inflammation-modulatory nanostimulators to stem cells for ischemic muscle repair. ACS Nano 14, 5298-5313. doi: 10.1021/acsnano. 9b04926

Lewin, M., Carlesso, N., Tung, C. H., Tang, X. W., Cory, D., Scadden, D. T., et al. (2000). Tat peptide-derivatized magnetic nanoparticles allow in vivo tracking and recovery of progenitor cells. Nat. Biotechnol. 18, 410-414. doi: 10.1038/ 74464

Li, Z., Huang, P., Zhang, X., Lin, J., Yang, S., Liu, B., et al. (2010). RGDconjugated dendrimer-modified gold nanorods for in vivo tumor targeting and photothermal therapy. Mol. Pharm. 7, 94-104. doi: 10.1021/mp9001415

Liu, C. B., Huang, H., Sun, P., Ma, S. Z., Liu, A. H., Xue, J., et al. (2016). Human umbilical cord-derived mesenchymal stromal cells improve left ventricular function, perfusion, and remodeling in a porcine model of chronic myocardial ischemia. Stem Cells Transl. Med. 5, 1004-1013. doi: 10.5966/sctm.20150298

Liu, X., Yang, Z., Sun, J., Ma, T., Hua, F., and Shen, Z. (2019). A brief review of cytotoxicity of nanoparticles on mesenchymal stem cells in regenerative medicine. Int. J. Nanomed. 14, 3875-3892. doi: 10.2147/ijn.s205574

Liu, Y. W., Chen, B., Yang, X., Fugate, J. A., Kalucki, F. A., Futakuchi-Tsuchida, A., et al. (2018). Human embryonic stem cell-derived cardiomyocytes restore function in infarcted hearts of non-human primates. Nat. Biotechnol. 36, 597605. doi: 10.1038/nbt.4162

Lu, W., Xie, Z., Tang, Y., Bai, L., Yao, Y., Fu, C., et al. (2015). Photoluminescent mesoporous silicon nanoparticles with siCCR2 improve the effects of mesenchymal stromal cell transplantation after acute myocardial infarction. Theranostics 5, 1068-1082.

Marbán, E., and Malliaras, K. (2012). Mixed results for bone marrow-derived cell therapy for ischemic heart disease. JAMA 308, 2405-2406. doi: 10.1001/jama. 2012.64751

Mathiasen, A. B., Qayyum, A. A., Jørgensen, E., Helqvist, S., Ekblond, A., $\mathrm{Ng}, \mathrm{M}$., et al. (2019). In vivo MRI tracking of mesenchymal stromal cells labeled with ultrasmall paramagnetic iron oxide particles after intramyocardial transplantation in patients with chronic ischemic heart disease. Stem Cells Int. 2019:2754927. doi: 10.1155/2019/2754927

Mecham, R. P. (2012). Overview of extracellular matrix. Curr. Protoc. Cell. Biol. 57, 10.1.1-10.1.16. doi: 10.1002/0471143030.cb1001s57

Michalet, X., Pinaud, F. F., Bentolila, L. A., Tsay, J. M., Doose, S., Li, J. J., et al. (2005). Quantum dots for live cells, in vivo imaging, and diagnostics. Science 307, 538-544. doi: 10.1126/science.1104274

Naseri, N., Valizadeh, H., and Zakeri-Milani, P. (2015). Solid lipid nanoparticles and nanostructured lipid carriers: structure, preparation and application. $A d v$. Pharm. Bull. 5, 305-313. doi: 10.15171/apb.2015.043 
Naseroleslami, M., Aboutaleb, N., and Parivar, K. (2018). The effects of superparamagnetic iron oxide nanoparticles-labeled mesenchymal stem cells in the presence of a magnetic field on attenuation of injury after heart failure. Drug Deliv. Transl. Res. 8, 1214-1225. doi: 10.1007/s13346-018-0567-8

Nethi, S. K., Mukherjee, S., Veeriah, V., Barui, A. K., Chatterjee, S., and Patra, C. R. (2014). Bioconjugated gold nanoparticles accelerate the growth of new blood vessels through redox signaling. Chem. Commun. 50, 14367-14370. doi: $10.1039 / \mathrm{c} 4 \mathrm{cc} 06996 \mathrm{j}$

Ni, D., Wei, H., Chen, W., Bao, Q., Rosenkrans, Z. T., Barnhart, T. E., et al. (2019). Ceria nanoparticles meet hepatic ischemia-reperfusion injury: the perfect imperfection. Adv. Mater. 31:e1902956. doi: 10.1002/adma.201902956

Ning, X. B. H., Liu, X., Fu, H., Wang, W., Huang, J., and Zhang, Z. (2019). Longterm in vivo CT tracking of mesenchymal stem cells labeled with Au@BSA@PLL nanotracers. Nanoscale 11, 20932-20941. doi: 10.1039/c9nr05637h

Nucci, L. P., Silva, H. R., Giampaoli, V., Mamani, J. B., Nucci, M. P., and Gamarra, L. F. (2015). Stem cells labeled with superparamagnetic iron oxide nanoparticles in a preclinical model of cerebral ischemia: a systematic review with meta-analysis. Stem Cell Res. Ther. 6:27. doi: 10.1186/s13287-0150015-3

Pack, D. W., Hoffman, A. S., Pun, S., and Stayton, P. S. (2005). Design and development of polymers for gene delivery. Nat. Rev. Drug Discov. 4, 581-593. doi: $10.1038 / \mathrm{nrd} 1775$

Park, H., Lee, J. W., Hwang, M. P., and Lee, K. H. (2013). Quantification of cardiovascular disease biomarkers via functionalized magnetic beads and ondemand detachable quantum dots. Nanoscale 5, 8609-8615. doi: 10.1039/ c3nr02357e

Patel, S., Jung, D., Yin, P. T., Carlton, P., Yamamoto, M., Bando, T., et al. (2014). NanoScript: a nanoparticle-based artificial transcription factor for effective gene regulation. ACS Nano 8, 8959-8967. doi: 10.1021/nn501589f

Patel, S., and Lee, K.-B. (2015). Probing stem cell behavior using nanoparticle-based approaches. Wiley Interdiscip. Rev. Nanomed. Nanobiotechnol. 7, 759-778. doi: 10.1002/wnan.1346

Paul, A., Nayan, M., Khan, A. A., Shum-Tim, D., and Prakash, S. (2012). Angiopoietin-1-expressing adipose stem cells genetically modified with baculovirus nanocomplex: investigation in rat heart with acute infarction. Int. J. Nanomed. 7, 663-682. doi: 10.2147/IJN.S26882

Peters, E. B. (2018). Endothelial progenitor cells for the vascularization of engineered tissues. Tissue Eng. Part B Rev. 24, 1-24. doi: 10.1089/ten.TEB.2017. 0127

Pietroiusti, A., Massimiani, M., Fenoglio, I., Colonna, M., Valentini, F., Palleschi, G., et al. (2011). Low doses of pristine and oxidized single-wall carbon nanotubes affect mammalian embryonic development. ACS Nano 5, 4624-4633. doi: $10.1021 / \mathrm{nn} 200372 \mathrm{~g}$

Piperigkou, Z., Karamanou, K., Engin, A. B., Gialeli, C., Docea, A. O., Vynios, D. H., et al. (2016). Emerging aspects of nanotoxicology in health and disease: from agriculture and food sector to cancer therapeutics. Food Chem. Toxicol. 91, 42-57. doi: 10.1016/j.fct.2016.03.003

Popara, J., Accomasso, L., Vitale, E., Gallina, C., Roggio, D., Iannuzzi, A., et al. (2018). Silica nanoparticles actively engage with mesenchymal stem cells in improving acute functional cardiac integration. Nanomedicine 13, 1121-1138. doi: 10.2217/nnm-2017-0309

Powers, K. W., Palazuelos, M., Moudgil, B. M., and Roberts, S. M. (2007). Characterization of the size, shape, and state of dispersion of nanoparticles for toxicological studies. Nanotoxicology 1, 42-51. doi: 10.1080/17435390701314902

Prajnamitra, R. P., Chen, H. C., Lin, C. J., Chen, L. L., and Hsieh, P. C. (2019). Nanotechnology approaches in tackling cardiovascular diseases. Molecules 24:2017. doi: 10.3390/molecules24102017

Qin, X., Chen, H., Yang, H., Wu, H., Zhao, X., Wang, H., et al. (2018). Photoacoustic imaging of embryonic stem cell-derived cardiomyocytes in living hearts with ultrasensitive semiconducting polymer nanoparticles. Adv. Funct. Mater. 28:1704939. doi: 10.1002/adfm.201704939

Rafieerad, A., Yan, W., Sequiera, G. L., Sareen, N., Abu-El-Rub, E., Moudgil, M., et al. (2019). Application of $\mathrm{Ti}(3) \mathrm{C}(2)$ MXene quantum dots for immunomodulation and regenerative medicine. Adv. Healthc. Mater. 8:e1900569. doi: 10.1002/adhm.201900569

Rehman, J., Traktuev, D., Li, J., Merfeld-Clauss, S., Temm-Grove, C. J., Bovenkerk, J. E., et al. (2004). Secretion of angiogenic and antiapoptotic factors by human adipose stromal cells. Circulation 109, 1292-1298. doi: 10.1161/01.cir. 0000121425.42966.f1

Ricles, L. M., Nam, S. Y., Sokolov, K., Emelianov, S. Y., and Suggs, L. J. (2011). Function of mesenchymal stem cells following loading of gold nanotracers. Int. J. Nanomed. 6, 407-416. doi: 10.2147/IJN.S16354

Risom, L., Møller, P., and Loft, S. (2005). Oxidative stress-induced DNA damage by particulate air pollution. Mutat. Res. 592, 119-137. doi: 10.1016/j.mrfmmm. 2005.06.012

Rosso, F., Giordano, A., Barbarisi, M., and Barbarisi, A. (2004). From cell-ECM interactions to tissue engineering. J. Cell. Physiol. 199, 174-180. doi: 10.1002/ jcp. 10471

Samuel, R., Daheron, L., Liao, S., Vardam, T., Kamoun, W. S., Batista, A., et al. (2013). Generation of functionally competent and durable engineered blood vessels from human induced pluripotent stem cells. Proc. Natl. Acad. Sci. U.S.A. 110, 12774-12779. doi: 10.1073/pnas.1310675110

Sánchez-López, E., Gomes, D., Esteruelas, G., Bonilla, L., Lopez-Machado, A. L., Galindo, R., et al. (2020). Metal-based nanoparticles as antimicrobial agents: an overview. Nanomaterials 10:292. doi: 10.3390/nano10020292

Satterlee, A. B., and Huang, L. (2016). Current and future theranostic applications of the lipid-calcium-phosphate nanoparticle platform. Theranostics 6, 918-929. doi: 10.7150/thno.14689

Shah, B. S., and Mao, J. J. (2011). Labeling of mesenchymal stem cells with bioconjugated quantum dots. Methods Mol. Biol. 680, 61-75. doi: 10.1007/9781-60761-901-7_4

Shiba, Y., Gomibuchi, T., Seto, T., Wada, Y., Ichimura, H., Tanaka, Y., et al. (2016). Allogeneic transplantation of iPS cell-derived cardiomyocytes regenerates primate hearts. Nature 538, 388-391. doi: 10.1038/nature19815

Singh, H., Du, J., and Yi, T. H. (2017). Green and rapid synthesis of silver nanoparticles using Borago officinalis leaf extract: anticancer and antibacterial activities. Artif. Cells Nanomed. Biotechnol. 45, 1310-1316. doi: 10.1080/ 21691401.2016.1228663

Singh, P., Kim, Y. J., and Yang, D. C. (2016). A strategic approach for rapid synthesis of gold and silver nanoparticles by Panax ginseng leaves. Artif. Cells Nanomed. Biotechnol. 44, 1949-1957. doi: 10.3109/21691401.2015.1115410

Singh, P., Pandit, S., Mokkapati, V., Garg, A., Ravikumar, V., and Mijakovic, I. (2018). Gold nanoparticles in diagnostics and therapeutics for human cancer. Int. J. Mol. Sci. 19:1979. doi: 10.3390/ijms19071979

Skelton, R. J., Khoja, S., Almeida, S., Rapacchi, S., Han, F., Engel, J., et al. (2016). Magnetic resonance imaging of iron oxide-labeled human embryonic stem cellderived cardiac progenitors. Stem Cells Transl. Med. 5, 67-74. doi: 10.5966/ sctm.2015-0077

Slowing, I. I., Vivero-Escoto, J. L., Wu, C. W., and Lin, V. S. (2008). Mesoporous silica nanoparticles as controlled release drug delivery and gene transfection carriers. Adv. Drug Deliv. Rev. 60, 1278-1288. doi: 10.1016/j.addr.2008.03.012

Sorokin, L. (2010). The impact of the extracellular matrix on inflammation. Nat. Rev. Immunol. 10, 712-723. doi: 10.1038/nri2852

Sun, C., Cao, Z., Wu, M., and Lu, C. (2014). Intracellular tracking of single native molecules with electroporation-delivered quantum dots. Anal. Chem. 86, 11403-11409. doi: 10.1021/ac503363m

Suzuki, Y., Zhang, S., Kundu, P., Yeung, A. C., Robbins, R. C., and Yang, P. C. (2007). In vitro comparison of the biological effects of three transfection methods for magnetically labeling mouse embryonic stem cells with ferumoxides. Magn. Reson. Med. 57, 1173-1179. doi: 10.1002/mrm.21219

Sylvester, A., Sivaraman, B., Deb, P., and Ramamurthi, A. (2013). Nanoparticles for localized delivery of hyaluronan oligomers towards regenerative repair of elastic matrix. Acta Biomater. 9, 9292-9302. doi: 10.1016/j.actbio.2013.07.032

Talkar, S., Dhoble, S., Majumdar, A., and Patravale, V. (2018). Transmucosal nanoparticles: toxicological overview. Adv. Exp. Med. Biol. 1048, 37-57. doi: 10.1007/978-3-319-72041-8_3

Tang, F., Li, L., and Chen, D. (2012). Mesoporous silica nanoparticles: synthesis, biocompatibility and drug delivery. Adv. Mater. 24, 1504-1534. doi: 10.1002/ adma.201104763

Tang, J., Wang, J., Yang, J., Kong, X., Zheng, F., Guo, L., et al. (2009). Mesenchymal stem cells over-expressing SDF-1 promote angiogenesis and improve heart function in experimental myocardial infarction in rats. Eur. J. Cardiothorac. Surg. 36, 644-650. doi: 10.1016/j.ejcts.2009.04.052

Tang, L., and Cheng, J. (2013). Nonporous silica nanoparticles for nanomedicine application. Nano Today 8, 290-312. doi: 10.1016/j.nantod.2013.04.007 
Tang, Y. L., Tang, Y., Zhang, Y. C., Qian, K., Shen, L., and Phillips, M. I. (2005). Improved graft mesenchymal stem cell survival in ischemic heart with a hypoxia-regulated heme oxygenase-1 vector. J. Am. Coll. Cardiol. 46, 1339-1350. doi: 10.1016/j.jacc.2005.05.079

Tapeinos, C., Battaglini, M., and Ciofani, G. (2017). Advances in the design of solid lipid nanoparticles and nanostructured lipid carriers for targeting brain diseases. J. Control. Release 264, 306-332. doi: 10.1016/j.jconrel.2017.08.033

Tarakanchikova, Y., Alzubi, J., Pennucci, V., Follo, M., Kochergin, B., Muslimov, A., et al. (2020). Biodegradable nanocarriers resembling extracellular vesicles deliver genetic material with the highest efficiency to various cell types. Small 16:e1904880. doi: 10.1002/smll.201904880

Tarhini, M., Greige-Gerges, H., and Elaissari, A. (2017). Protein-based nanoparticles: from preparation to encapsulation of active molecules. Int. J. Pharm. 522, 172-197. doi: 10.1016/j.ijpharm.2017.01.067

Toma, C., Pittenger, M. F., Cahill, K. S., Byrne, B. J., and Kessler, P. D. (2002). Human mesenchymal stem cells differentiate to a cardiomyocyte phenotype in the adult murine heart. Circulation 105, 93-98. doi: 10.1161/hc0102.101442

Tu, C., Das, S., Baker, A. B., Zoldan, J., and Suggs, L. J. (2015). Nanoscale strategies: treatment for peripheral vascular disease and critical limb ischemia. ACS Nano 9, 3436-3452. doi: 10.1021/nn507269g

Urdzíková, L., Jendelová, P., Glogarová, K., Burian, M., Hájek, M., and Syková, E. (2006). Transplantation of bone marrow stem cells as well as mobilization by granulocyte-colony stimulating factor promotes recovery after spinal cord injury in rats. J. Neurotrauma 23, 1379-1391. doi: 10.1089/neu.2006.23.1379

van der Spoel, T. I., Jansen of Lorkeers, S. J., Agostoni, P., van Belle, E., Gyöngyösi, M., Sluijter, J. P., et al. (2011). Human relevance of preclinical studies in stem cell therapy: systematic review and meta-analysis of large animal models of ischaemic heart disease. Cardiovasc. Res. 91, 649-658. doi: 10.1093/cvr/cvr113

Verma, A., and Stellacci, F. (2010). Effect of surface properties on nanoparticle-cell interactions. Small 6, 12-21. doi: 10.1002/smll.200901158

Vilahur, G., Oñate, B., Cubedo, J., Béjar, M. T., Arderiu, G., Peña, E., et al. (2017). Allogenic adipose-derived stem cell therapy overcomes ischemiainduced microvessel rarefaction in the myocardium: systems biology study. Stem Cell Res. Ther. 8:52. doi: 10.1186/s13287-017-0509-2

Vulliet, P. R., Greeley, M., Halloran, S. M., MacDonald, K. A., and Kittleson, M. D. (2004). Intra-coronary arterial injection of mesenchymal stromal cells and microinfarction in dogs. Lancet 363, 783-784. doi: 10.1016/s0140-6736(04) 15695-x

Wang, B., Tan, L., Deng, D., Lu, T., Zhou, C., Li, Z., et al. (2015a). Novel stable cytokine delivery system in physiological $\mathrm{pH}$ solution: chitosan oligosaccharide/heparin nanoparticles. Int. J. Nanomed. 10, 3417-3427. doi: 10.2147/ijn.s82091

Wang, G., Zeng, G., Wang, C., Wang, H., Yang, B., Guan, F., et al. (2015b). Biocompatibility of quantum dots (CdSe/ZnS) in human amniotic membranederived mesenchymal stem cells in vitro. Biomed. Pap. Med. Fac. Univ. Palacky Olomouc. Czech. Repub. 159, 227-233. doi: 10.5507/bp.2014.045

Wenbin, L., Zhou, X., Yong, T., Ling, B., Yu, Y., Fu, C., et al. (2015). Photoluminescent mesoporous silicon nanoparticles with siCCR2 improve the effects of mesenchymal stromal cell transplantation after acute myocardial infarction. Theranostics 5, 1068-1082. doi: 10.7150/thno.11517
Xiang, S., Tong, H., Shi, Q., Fernandes, J. C., Jin, T., Dai, K., et al. (2012). Uptake mechanisms of non-viral gene delivery. J. Control. Release 158, 371-378. doi: 10.1016/j.jconrel.2011.09.093

Yang, F., Green, J. J., Dinio, T., Keung, L., Cho, S. W., Park, H., et al. (2009). Gene delivery to human adult and embryonic cell-derived stem cells using biodegradable nanoparticulate polymeric vectors. Gene Ther. 16, 533-546. doi: 10.1038/gt.2008.182

Ye, L., Zhang, W., Su, L. P., Haider, H. K., Poh, K. K., Galupo, M. J., et al. (2011). Nanoparticle based delivery of hypoxia-regulated VEGF transgene system combined with myoblast engraftment for myocardial repair. Biomaterials 32, 2424-2431. doi: 10.1016/j.biomaterials.2010.12.008

Yohan, D., and Chithrani, B. D. (2014). Applications of nanoparticles in nanomedicine. J. Biomed. Nanotechnol. 10, 2371-2392. doi: 10.1166/jbn.2014. 2015

Yun, C. W., and Lee, S. H. (2019). Enhancement of functionality and therapeutic efficacy of cell-based therapy using mesenchymal stem cells for cardiovascular disease. Int. J. Mol. Sci. 20:982. doi: 10.3390/ijms20040982

Zhang, L., Gu, F. X., Chan, J. M., Wang, A. Z., Langer, R. S., and Farokhzad, O. C. (2008). Nanoparticles in medicine: therapeutic applications and developments. Clin. Pharmacol. Ther. 83, 761-769. doi: 10.1038/sj.clpt.6100400

Zhang, M., Methot, D., Poppa, V., Fujio, Y., Walsh, K., and Murry, C. E. (2001). Cardiomyocyte grafting for cardiac repair: graft cell death and anti-death strategies. J. Mol. Cell. Cardiol. 33, 907-921. doi: 10.1006/jmcc.2001.1367

Zhu, K., Guo, C., Lai, H., Yang, W., Xia, Y., Zhao, D., et al. (2011). Novel hyperbranched polyamidoamine nanoparticles for transfecting skeletal myoblasts with vascular endothelial growth factor gene for cardiac repair. J. Mater. Sci. Mater. Med. 22, 2477-2485. doi: 10.1007/s10856-011-4424-2

Zhu, K., Wu, M., Lai, H., Guo, C., Li, J., Wang, Y., et al. (2016). Nanoparticleenhanced generation of gene-transfected mesenchymal stem cells for in vivo cardiac repair. Biomaterials 74, 188-199. doi: 10.1016/j.biomaterials.2015.10. 010

Zhu, M. L., Wang, G., Wang, H., Guo, Y. M., Song, P., Xu, J., et al. (2019). Amorphous nano-selenium quantum dots improve endothelial dysfunction in rats and prevent atherosclerosis in mice through $\mathrm{Na}(+) / \mathrm{H}(+)$ exchanger 1 inhibition. Vascul. Pharmacol. 115, 26-32. doi: 10.1016/j.vph.2019. 01.005

Zuk, P. A., Zhu, M., Mizuno, H., Huang, J., Futrell, J. W., Katz, A. J., et al. (2001). Multilineage cells from human adipose tissue: implications for cell-based therapies. Tissue Eng. 7, 211-228. doi: 10.1089/107632701300062859

Conflict of Interest: The authors declare that the research was conducted in the absence of any commercial or financial relationships that could be construed as a potential conflict of interest.

Copyright (C) 2020 Sun, Lu, Yin and Liu. This is an open-access article distributed under the terms of the Creative Commons Attribution License (CC BY). The use, distribution or reproduction in other forums is permitted, provided the original author(s) and the copyright owner(s) are credited and that the original publication in this journal is cited, in accordance with accepted academic practice. No use, distribution or reproduction is permitted which does not comply with these terms. 